
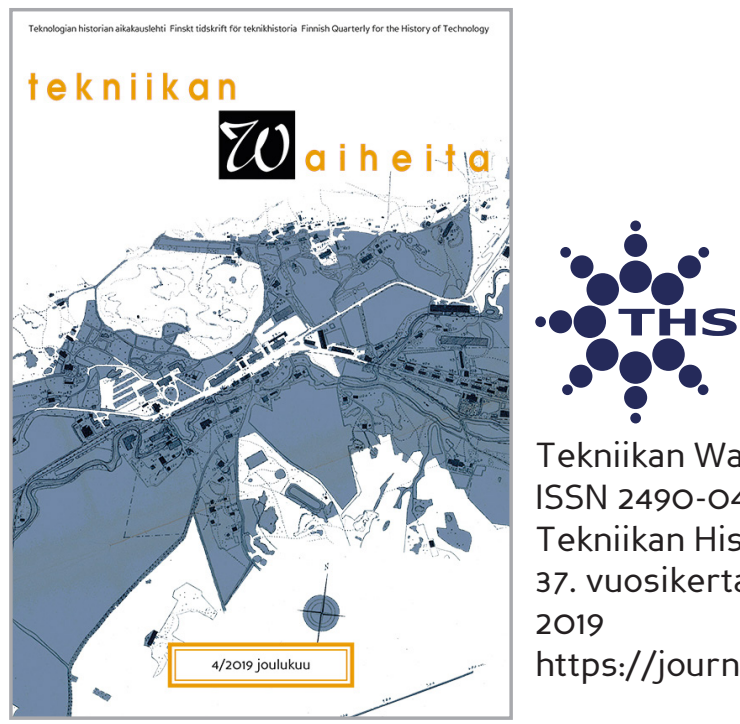

Tekniikan Waiheita

ISSN 2490-0443

Tekniikan Historian Seura ry.

37. vuosikerta:4

2019

https://journal.fi/tekniikanwaiheita

Möhkön ruukkikylä kulttuurikohteena ja luonnonvarojen muuttuva arvostus

Jukka Sihvonen \& Hilkka Heinonen

To cite this article: Jukka Sihvonen \& Hilkka Heinonen, ’Möhkön ruukkikylä kulttuurikohteena ja luonnonvarojen muuttuva arvostus" Tekniikan Waiheita 37, no. 4 (2019): 57-72. https://dx.doi.org/10.33355/tw.88911

To link to this article: https:/ /dx.doi.org/10.33355/tw.88911 


\title{
Möhkön ruukkikylä kulttuurikohteena ja luonnonvarojen muuttuva arvostus
}

\author{
Jukka Sihvonen' \& Hilkka Heinonen²
}

Tässä artikkelissa tarkastellaan teollisen ruukin vaiheita ja kulttuuriperinnön hyödyntämistä alueella, jossa luonnonvarojen käyttö on elinkeinojen perusta. Suomessa lukuisat ruukit ovat Museoviraston suojeluksessa. Ruukit ovat kulttuuriperintökohteita, jotka toimivat palveluelinkeinojen, kuten matkailun perustana. Ruukkiyhdyskunnat ja niiden lähiympäristöt ovat tärkeitä kulttuuri- ja luontomatkailukohteita. Ruukkikylän läheisyydessä olevien luonnonvarojen hyödyntäminen vaikuttaa kulttuuri- ja luontomatkailun edellytyksiin. Artikkelin lähtökohtana on kysymys, kuinka entiseen teolliseen - mutta nykyisin kulttuuriperintöä hyödyntävään - yhdyskuntaan vaikuttaa ympäröivien luonnonvarojen teollinen käyttö ja käytön oikeudellisesti vahva asema. Kohteena on Möhkön ruukki, jonka nykytilaa tarkastellaan luonto- ja kulttuurimatkailun ja luonnonvarayhtiöiden ristivetoisten tavoitteiden näkökulmasta. ${ }^{3}$

Möhkön rautaruukki oli toiminnassa vuosina 1838-1907 ja se on tärkeä osa Suomen metalliteollisuuden ja maaseutuyhdyskuntien kehittymisen historiaa. Ruukilla oli aikanaan vahva sidos ympäröivään seutuun. Ruukin puunhankintaa säänneltiin senaatin lupakäytäntöjen avulla. Toinen maailmansota muutti Möhkön aseman rajavyöhykkeellä olevaksi syrjäiseksi kyläksi, jonka itäpuoliset luonnonvarat jäivät Venäjän puolelle. Muutenkin aika ajoi järvimalmin ja uittojen ohi. Kylään jäivät kuitenkin ruukin rakenteet, muotoutuneet maanomistusolot sekä sotahistorian muistot. Sittemmin kulttuurimaisema on tunnustettu suojelukohteena ja sotahistoriallisia kohteita tutkitaan ja kunnostetaan nähtävyyksiksi. Ruukkikylän elinvoiman keskeisiä elementtejä ovat kulttuuriperintö, sotahistorialliset lähikohteet ja ruukkia ympäröivä luonnonympäristö.

\section{Ruukit raudantuottajista kulttuurikohteiksi}

\section{Ruukkiympäristöjen teollinen perintö, kulttuuritutkimus ja matkailukäyttö}

Varhaiset järvimalmia hyödyntävät ruukit ovat olleet merkittäviä toimijoita Suomen rautametallin tuotannossa ja valtiotalouden kannalta. Niissä on kehitetty pitkälti puuenergiaan perustuvia raudan sulattamis- ja valamismenetelmiä. Ruukit ovat tärkeä osa Suomen metalliteollista historiaa, ja niihin on paikantunut myös erilaisia historiallisten tapahtumien vaiheita. Heidi Grahnin (2013) mukaan Suomen vuoriteollisuuden perusta ajoittuu vuoteen 1637,

\footnotetext{
${ }^{1} \mathrm{FL}$ Jukka Sihvonen on ympäristöpolitiikan yliopisto-opettaja ja projektitutkija Itä-Suomen yliopistossa. Hän on toiminut tutkijana lukuisissa ympäristöhallintaa koskevissa tutkimus- ja kehittämishankkeissa. Nykyään hän työskentelee pääasiassa yhteiskuntatieteellisissä kaivostoiminnan tutkimusprojekteissa.

${ }^{2}$ Oikeustieteiden tohtori ja filosofian maisteri Hilkka Heinonen on ympäristöoikeuden lehtori Itä-Suomen yliopistossa. Hän on toiminut tutkijana lukuisissa ympäristöhallinnon ja lainsäädännön tutkimus- ja kehityshankkeissa. Hänen kiinnostuksensa kohdistuu tällä hetkellä erityisesti luonnonvarakiistojen sovittelun oikeudellisiin kysymyksiin.

${ }^{3}$ Artikkelin taustalla on llomantsin Koitajoen valuma-alueen luonnonvarojen käyttöä yhteensovittava kokeilu-, kehittämis- ja tutkimushanke SOVIKO, sovittelu ja yhteishallinta ympäristöpäätöksenteossa. Itä-Suomen yliopisto / Maj ja Tor Nesslingin säätiö, 2017-2018).
} 
jolloin Ruotsin hallinto perusti Vuorikollegion. Se myönsi teolliset toimintaluvat, määritteli ruukkien vuosittaiset taontaoikeudet ja verot. Suomessa on ollut yli 80 rautaa ja kuparia valmistavaa teollista ruukkia. ${ }^{4}$ Kaikkiaan Suomessa on toiminut 134 ruukkilaitosta, joista eräät ovat edelleen toiminnassa metallituotteita valmistavina laitoksina.

Ruukkien katsotaan kuuluvan kartanoruukkiteollisuuteen, sillä ruukit olivat tyypillisesti yksityisten henkilöiden tai sukujen omistuksessa. Ruukkien raaka-aineena oli lähialueen järvi- ja suomalmeja. Myös vuorimalmia käytettiin, mutta siitä merkittävä osa tuotiin laivoilla Ruotsista. Ruukkiteollisuus tarvitsi suuret maa- ja metsäalueet, sillä puuta hyödynnettiin hiilen valmistukseen. Virtaava vesi oli käyttövoimana ruukkien elinehto ja siksi ne sijoittuivat aina koskien varrelle. Ruukit olivat aikansa malmia sulattavia ja rautaa valmistavia metalliteollisia järjestelmïa. Laajemmat kokonaisuudet sisälsivät myös manufaktuuriteollisuutta. ${ }^{5}$

Jokien rantaympäristöön rakennetut masuunit, varastot ja metallituotteita valmistavat manufaktuuripajat, asuin- ja palvelurakennukset sekä ruukkikartanot ovat ruukkimiljöön keskeisiä elementtejä. Monia niistä on myös restauroitu matkailu- ja vapaa-ajan kohteiksi. Useissa Suomen ruukkikylissä järjestetään taidenäyttelyjä ja monen ruukin miljööt ja rakennukset tarjoavat pysyviä tai väliaikaisia työtiloja taiteilijoille ja käsityöläisille. Ruukkikartanoita ovat suunnitelleet arkkitehdit ja rakentaneet aikakautensa osaavat ja taitavat rakentajamestarit. Ruukit ovat asiantuntijoiden inventoimia tunnustettuja kulttuuriympäristöjä.

Ruukkeihin liitettyjä merkityksiä on muotoutunut sekä tutkimusten että paikallisten tarinoiden pohjalta. Ruukkiympäristöjä on tutkittu ja määritetty yrityshistorioiden yhteydessä paljolti taidehistoriallisesta ja rakennuskulttuurisesta näkökulmasta ${ }^{6}$. Ruukit ovat olleet myös teollisuusarkeologisten inventointitutkimusten kohteena, mm. matkailukohteeksi saattamisen restaurointitöiden yhteydessä7. Maarit Grahnin (2014) tutkimus A. Ahlström Osakeyhtiön Noormarkun ruukin vaiheista kertoo, miten historiaa käytetään yrittämisen vahvuutena ja kuinka historiatietoisuus myös ohjaa yrityksen sopeutumista toiminnan muutosvaiheissa. Kulttuuriperintöä käytetään tulevaisuuteen suuntautuvan muutoksen hallinnassa, ja välineinä toimivat arkistot, museot, näyttelyt ja yrityshistorialliset julkaisut sekä 2000-luvulla myös internet. Samalla yhtiö pyrkii ylläpitämään vastuuta paikallisyhteisöstä. ${ }^{8}$ Ruukit ovat edelleen myös asumisen ja työn paikkoja, jolloin asukkaiden ja toimijoiden muisti- ja kokemusperäinen tieto on myös tutkimuksellisen mielenkiinnon kohde ja niitä käytetään muun muassa ruukkeja koskevien suunnitelmien tiedollisina perusteina'. Ruukkiyhdyskunnan kulttuuriperintö avaa mahdollisuuden myös ruukkiyhdyskuntaa lähellä olevien ympäristöjen kulttuuristen ja ympäristöllisten arvojen esiin nostamiseen. Se tarvitsee paikallishistoriaan liittyvän muistitiedon keräämistä, erilaisten tarinoiden ja tapahtumien todentamista. Siinä voidaan käyttää apuna yhdyskuntatutkimusta tai soveltavaa kulttuuritutkimusta ${ }^{10}$ ja tarvittaessa konfliktitutkimusta ${ }^{11}$. Ongelmaratkaisutilanteissa olennaista on eri toimijoiden vuorovaikutteisten kohtaamisten järjestäminen, joiden avulla voidaan myös asettaa yhteistoiminnallisia tai -hallinnallisia tavoitteita.

\footnotetext{
${ }^{4}$ Grahn 2013,4 https://www.salo.fi/attachements/2015-10-06T08-08-4992.pdf

${ }^{5}$ GTK 2002. http://weppi.gtk.fi/aineistot/kaivosteollisuus/RUUKIT.htm

${ }^{6}$ Korvenmaa 1989.

${ }^{7}$ Kallio, Titta 2005, 48.

${ }^{8}$ Grahn 2014, 34-43. https://www.utupub.fi/handle/10024/94239

${ }^{9}$ Kujala 2006. https://trepo.tuni.fi/bitstream/handle/10024/93554/graduo1149.pdf? sequence $=1 \&$ isAllowed $=y$

10 Haanpää et. al. 2018.

${ }^{11}$ Peltonen \& Villanen 2004.
} 


\section{Ruukkien kulttuuriperinnön suojelusta ja luontosidonnaisuudesta}

Kulttuuriperintö voidaan nähdä välineellisessä merkityksessä. Sen avulla voidaan rakentaa tai ylläpitää identiteettiä ${ }^{12}$. Kulttuuriperintökohteet voivat olla virallisiksi luokiteltuja paikkoja, esineitä, tapoja. Tällöin virallinen kulttuuriperintö näyttäytyy museoissa, kansallisissa muistomerkeissä ja muissa instituutioiden hyväksymissä käsityksissä, kuten Unescon maailmanperintöluettelossa. Virallista kulttuuriperintöä voidaan pitää passiivisen kulutuksen kohteena ${ }^{13}$. Kulttuuriperintöä hyödynnetään näytelmien, käsityönäytöksien ja tarinoihin kytkeytyvien paikkojen ja maisemien avulla, se avaa mahdollisuuksia turistipohjaisille elinkeinoille ${ }^{14}$. Kulttuuriperinnöllä on myös epävirallinen puoli. Epävirallinen kulttuuriperintö muotoutuu ruohonjuuritasolta ja suuntautuu 'alhaalta ylöspäin'. Se sisältää paikallisia tapahtumia, kuten festivaaleja ja perustuu aktiiviseen osallistumiseen sekä luovaan tekemiseen ${ }^{15}$. Toiminnassa esillä ovat paikalliset kokemukset ja asukkaiden kertomukset. Ne ovat muistitietoa, jonka pohjalta esimerkiksi maisemaa kohtaan voi syntyä ns. empaattinen omistajuus (landscape stewardship) ${ }^{16}$. Tämä tiedostettu (epävirallinen) ympäristösuhde on paikallisesti merkityksellinen, mutta sitä ei voida välttämättä ottaa huomioon esimerkiksi lakisääteisissä luvissa. Sen vuoksi tarvitaan erilaisia dialogisia käytäntöjä, joiden avulla kulttuuriperintökohde tulee ymmärretyksi laajemmassa merkitysyhteydessä.

Usein ruukkeja ympäröivä luonto muodostaa oleellisen osan ruukin kokonaismiljööstä. Ruukkien toiminnan aikaiset tai sitä myöhemmät teot ovat jättäneet jälkiä ympäröivään luontoon. Ruukkien kulttuuriperinnössä luonto ja kulttuuri yhdistyvät. Ympäristönäkökohdat ovat osa kulttuuriperintöä ja niiden kulttuurisidonnaisuus voi olla syy ympäristön säilyttämiseen, koska tietyillä paikoilla on merkitystä sekä yksilöille että yhteisöille.

Ympäristön perintöulottuvuus ja narratiivinen arvo pitää kuitenkin tunnistaa. Ne voivat sisältää tarinoita, jotka yhdistävät meidät menneisyyteen. Ongelma on siinä, mitä tarinoiden arvo tarkoittaa käytännössä. Historiallisten narratiivien muotoilussa ja levittämisessä paikkakertomukset ovat tärkeitä, mutta niiden arvo tulee todentaa. ${ }^{17}$ Ruukkien lähiympäristöön paikantuvilla tarinoilla voi siten olla merkittäviä kulttuurisia arvoja maisemaa hyödyntävissä tavoitteissa, mutta ne jäävät helposti tunnistamatta luonnonvarojen käytön suunnitelmissa.

\section{Möhkön ruukki toistaa yleistä ruukkien historiaa}

Möhkö sijaitsee 25 kilometriä Ilomantsin keskustasta itään Suomen ja Venäjän rajan läheisyydessä, Venäjän puolelta Suomeen palaavan Koitajoen varrella. Kylän keskustasta on vajaa kolme kilometriä rajalle ja 1,5 km rajavyöhykkeen reunaan. Kylällä on pitkä teollisuus- ja voimalaitoshistoria. Möhkön kylän historiassa merkittävä tekijä on sen paikka Nuorajärveen laskevan Koitajoen varrella. Koitajoki on ollut tärkeä kauppareitti.

\footnotetext{
12 Siivonen 2012, 176. http://www.elore.fi/arkisto/1_12/siivonen.pdf

${ }^{13}$ Fairclough 2012, 15.

${ }^{14}$ Rojek 1993 146-152; myös Kahila 2001, 151.

${ }^{15}$ Fairclough 2012, 15.

${ }^{16}$ Haanpää et.al. 2018, 191.

${ }^{17}$ Matthes 2018. https://plato.stanford.edu/archives/fall2018/entries/ethics-cultural-heritage/
} 


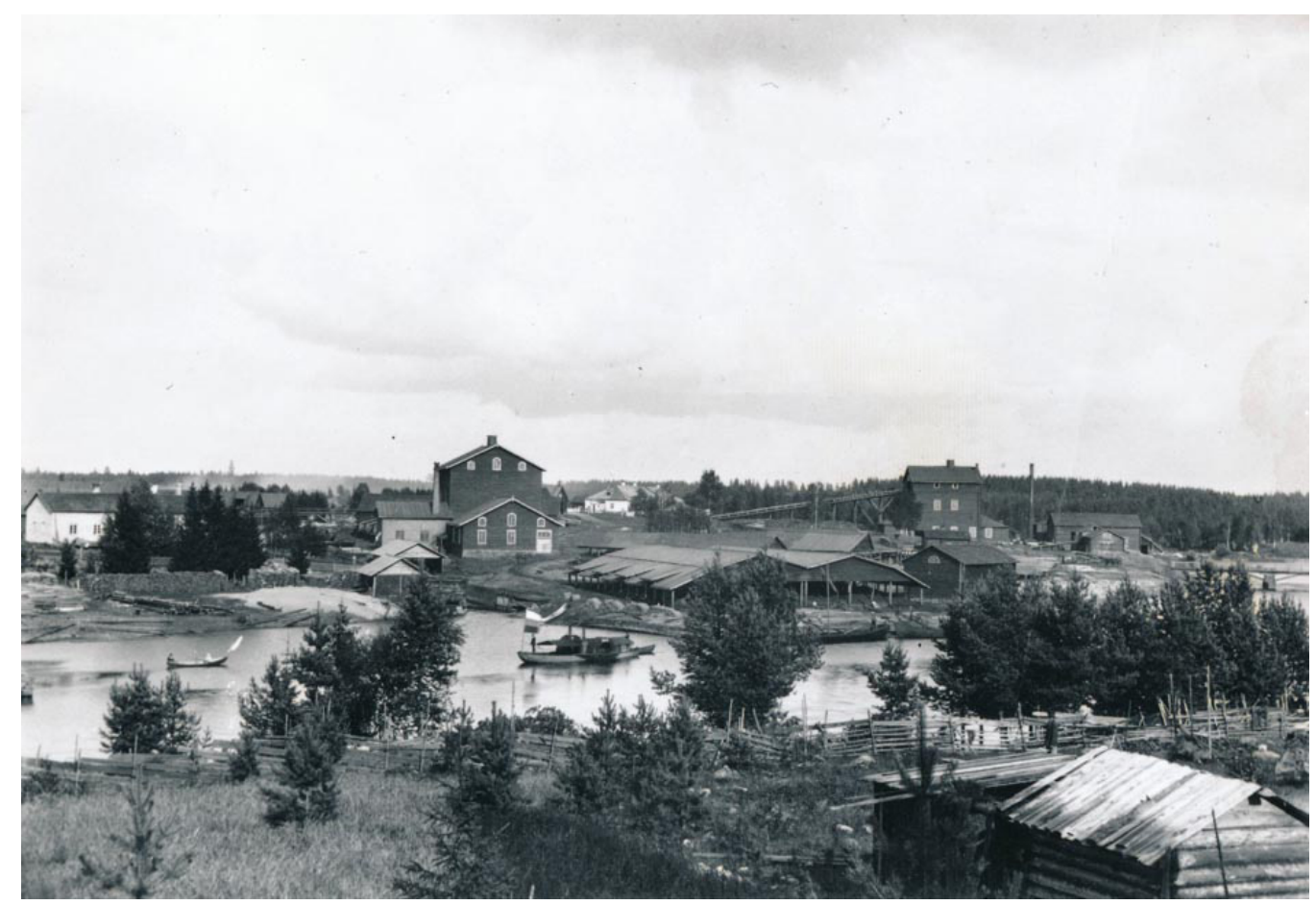

Kuva 1. Möhkön ruukki 1880-luvulla. Kuvaaja Jean Schmidt. Ilomantsin Museosäätiö.

Adolf von Rauch perusti Möhköön järvimalmia hyödyntävän rautaruukin vuonna 1849. Ilomantsin järvet sisälsivät järvimalmia ja Möhkön koskesta saatiin sen koneelliseen (puhalluskone) prosessointiin vaadittava vesivoima. Sahateollisuusmies ja suurmaanomistaja Nils Ludwig Arppe (1801-1861) osti ruukin vuonna 1851. Arppe laajensi ruukkia ja modernisoi aiemmin rakennetun padon turvin toimivan ruukin tekniikkaa. Tätä varten hän palkkasi tehtaan rakentamiseen ulkomaalaisia teollisuusammattilaisia ja teknisiä asiantuntijoita. ${ }^{18}$

1850-luvulla Möhköön rakennettiin uusi masuuni, konepaja ja valimo. Niiden lisäksi valmistuivat myös uusimman tekniikan mukaiset puhallin sekä vesitornit. Ne mahdollistivat suuren tuotannon ja tuotteiden korkealaatuisuuden. Arppen toimilupa myönnettiin sillä ehdolla, että von Rauchin rakentama pato puretaan. Näin tehtiinkin, mutta vesivoima oli välttämätöntä käyttövoimana ja pato rakennettiin uudelleen vuonna 1865. Sitä ennen vuonna 1861 tulipalo oli ehtinyt tuhota masuunirakennuksen, konehuoneen ja höyryhuoneen, mutta uuden rakentaminen aloitettiin välittömästi ja ruukki oli vuotta myöhemmin jälleen tuotannossa. ${ }^{19}$

Prosessi vaati paljon puuta, halkoja. Puuta hankittiin sekä hiilen tuotantoon että ruukin rakenteita varten mm. Arppen omistuksessa olevista laajoista metsistä sekä muualtakin erillisten sopimusten avulla. Aikaisemman omistajan keskeinen hankinta-alue oli ruukkia lähellä oleva Nuorajärven ympäristö. Senaatti kuitenkin rajasi puunhankinta-alueen kokoa, koska

\footnotetext{
18 Björn 1991, 363.

${ }^{19}$ Björn 1991, 365.
} 
laajan alueen valvonta oli vaikea tehtävä. Kaikkiaan hiilenhankinta, raudannosto ja kuljetukset työllistivät satoja työntekijöitä. Möhköstä kehkeytyi merkittävä kauppapaikka ja teollinen keskus. Vuonna 1857 Möhkössä tuotettiin 3276 tonnia takkirautaa. Rauta oli erityisen tärkeä teollisesti tuotettujen välineiden materiaali ja merkittävä kauppatuote maailman kaupassa. Venäjän ja Suomen välinen kauppa-asetus lisäsi rautateollisuustuotteiden menekkiä ja Arppe modernisoi tuotantolaitostaan edelleen. Raaka-aineen hankintaa varten Möhkön ruukki valtasi useita järviä, joista osa hyödynnettiin malmin nostoon. Tärkein raaka-ainelähde oli Koitere. Järvimalmia kuljetettiin Möhköön hevoskyydeillä, veneillä ja proomuilla. Ruukin valmiit tuotteet toimitettiin Värtsilään ja sieltä edelleen Pietariin Möhkön ruukin omistamiin makasiineihin, joista tuote sitten mytiin markkinoilla. ${ }^{20}$

Seuraavan 50 vuoden aikana Möhköstä kehittyi merkittävä 600 asukkaan kylä ja palvelukeskus. Arppen yhtiö mahdollisti palvelut ja rakensi niihin tarvittavat rakennukset. Möhkön ruukki, kuten muutkin tehdas- ja ruukkiyhteisöt olivat pitäjän määräysvallan suhteen autonomisia yhteisöjä. Ruukkikylissä toimi sairaala, oli koulu ja joissain ruukeissa toimi myös itsenäinen seurakunta. Ilomantsin ensimmäinen kansakoulu perustettiin 1858 tehtaan lapsille Möhköön. Uusi kansakoulurakennus valmistui Möhköön vuonna 1879, mikä myös edesauttoi muiden kyläkoulujen rakentamista Ilomantsiin. Laajempi kansakoulu perustettiin Möhköön vuonna 1928. ${ }^{21}$

Kaivostoiminnalle tyypilliset suhdanteet ja uudet käytännöt hiljensivät järviraudan kysyntää ja ruukin toiminta päättyi vuonna 1908. Alueen metsät ja Koitajoki mahdollistivat edelleen työn ja toimeentulon kyläläisille. Malmitehdas ja Arppen Ilomantsin metsäomaisuus, jota oli yhteensä yli 100000 hehtaaria, siirtyivät samana vuonna norjalaisen Gutzeitin omistukseen. 1920-luvulla valtio pakkolunasti metsäyhtiöiden maita ns. Lex Kallion perusteella ja luovutti niitä maan tarpeessa oleville henkilöille. Möhkön seudulle kasvoi pienviljelijäväestö, joka sai lisäansioita metsäyhtiöiden tarjoamista kausiluonteisista metsätöistä. Möhköön oli rakennettu saha jo vuonna 1871 ja sahaustoiminta jatkui aina vuoteen 1960 saakka. ${ }^{22}$

\section{Möhkön kylä ja muuttuvat luonnonvaraintressit}

\section{Kulttuurihistorian ja ympäristön hyödyntäminen Möhkön matkailussa}

Möhkön ruukki on yksi Suomen tärkeimmistä järvimalmiruukkitoiminnan muistomerkeistä, jonka rakenteita Museovirasto restauroi vaiheittain ajanjaksolla 1989-2006 ${ }^{23}$. Teollisen perinnön suojelun ansiosta historialliset ruukkimiljööt ovat muodostuneet myös tärkeiksi matkailukohteiksi ${ }^{24}$.

Runkkimuseossa voi tutustua järvimalmin sulatuksen tekniseen järjestelmään. Kokonaisuuteen kuuluvat sepän paja ja masuuni sekä jäljellä olevat rakenteet alueen läpi virtaavasta kanavasta. Raudanvalmistuksen teollisuusrakennukset ovat pääosin hävinneet. Mäenlaella

\footnotetext{
${ }^{20}$ Mustelin 1973, 193-220; Björn 1991, 367-368.

${ }^{21}$ Björn 1991,159; Ikonen 2015, 160.

22 Björn 2006; Ikonen 2015.

${ }^{23}$ Museovirasto restauroi 2013. http://museovirastorestauroi.nba.fi/teollisuuskohteet/mohkon-ruukki

${ }^{24}$ Immonen, V., et. al. 2018. https://journal.fi/tekniikanwaiheita/article/view/82367-
} 
puistomaisessa ympäristössä sijaitseva Ruukinkartano on restauroitu majoitus- ja ravintolakäyttöön. Ruukin hautausmaa sijaitsee harjanteella kyläkeskuksen koilliskulmauksessa. ${ }^{25}$ Ruukkikylässä Koitajoen rannalla oleva asuntoproomu Möhkön Manta edustaa Ilomantsin ja lähinnä Koitereen ja Koitajoen uittoperinnettä. Vuonna 1955 uittojätkien asuntolaksi valmistunut alus toimi Koitajoella paikasta toiseen siirrettävänä kämppänä. Nykyään proomu toimii ruukkikylän kesäkahvilana. ${ }^{26}$ Näiden lisäksi kyläkokonaisuuteen kuuluu myös Ruukin puulajiphisto.

Ruukkimuseon restauroitu kokonaisuus muodostaa pohjan ruukkikylän uusille elinkeinoille, pääasiassa luonto-, matkailu- ja kulttuuriyrittäjyydelle. Ruukin historian lisäksi muillakin historiallisilla kerrostumilla ja luonnonympäristön laadulla on näille yrityksille merkittävä käyttöarvo. Etenkin sotahistorialliset tapahtumat ovat tärkeä matkailuelementti. Kylämatkailun kehittämishankkeen raportissa (2014) Möhkön osalta todettiin, että rautaruukin ja metsätyön historian rinnalle on sotahistoria noussut merkittäväksi vahvuudeksi. Myös kylän läheinen luonto ja Petkeljärven kansallispuisto ovat tärkeitä kylän kannalta. Raportin kehittämissuosituksena on, että " museaalista ajattelua laajennetaan sekä esihistorialliseen että lähihistorian suuntaan (sodan jälkeen, 60-luku)" ${ }^{27}$

Möhkö oli neuvostodivisioonan miehittämä talvisodassa joulukuusta 1939 maaliskuun 1940 rauhaan saakka. Vuonna 1944 jatkosodan loppuvaiheissa Hattuvaaran - Möhkön välisellä alueella käydyt taistelut olivat merkitykseltään ratkaisevia koko sodan lopputuloksen kannalta. Näitä taisteluiden jälkiä on edelleen näkyvillä ${ }^{8}$. Nämä sekä evakkojen kohtalo ja sodanjälkeinen jälleenrakennuksen aika on taltioitu "Möhkö sodassa" -näyttelyyn ruukin päärakennukseen. Lisäksi noin viisi kilometriä Möhköstä itärajan suuntaan sijaitsee Öykkösenvaaran sotahistoriallinen alue, joka kuului Ilomantsin puolustuslinjaan. ${ }^{29}$ Möhkön ruukkikylän nykyiset toimijat hyödyntävät ruukkikylän teollisen perinnön lisäksi näitä lähistön metsäalueilla sijaitsevia sotahistoriallisia kohteita, joita on tutkittu, entistetty ja tarinallistet$\mathrm{tu}^{30}$. Historiallisten muistin paikkojen rakentaminen, kuten sotahistoriaan painottuva maisemakierros, voidaan nähdä aineettomien matkailupalvelujen kehittämisenä. Kysymyksessä on aluekokonaisuus, joka yhdistää luonnon ympäristöä ja "ei-virallista kulttuuriympäristöä".

Ruukkikylässä toimii vuosittainen kesäteatteri ja kylässä järjestetään konsertteja, tapahtumia, kokouksia, yms. Lähiympäristössä olevat historiallisesti merkittävät paikat ovat kotiseututoiminnan kohteita, joiden merkitys voi korostua tarinoiden esittämisen, esimerkiksi näytelmien, myötä. Sillä tavoin ne kytkeytyvät kulttuuriperinnön säilyttämiseen ja vahvistamiseen ruukkikylän voimavarana. Ruukkimuseossa on myös vuosittain esillä nykytaiteen näyttely.

Möhkön seudulla luontomatkailulle on monipuoliset puitteet. Möhkön ruukkia ympäröivää seutua luonnehtii erämaisuus, suoluonto ja metsäisyys. Myös kylän läpi virtaava Koitajoki ja kylän läheiset järvet, Nuorajärvi, Sysmä, Mekrijärvi ja Petkeljärvi sekä Ilajanjävi ja Viinijärvi kytkeytyvät ruukin historiaan ja nykypäivään. Möhkön ruukkiyhdyskunta sekä Metsähallituksen hallinnoima Petkeljärven kansallispuisto muodostavat laajan kulttuuri- ja

\footnotetext{
${ }^{25}$ Museovirasto 2009. http://www.rky.fi/read/asp/r_default.aspx

${ }^{26}$ Ikonen 2015.

${ }^{27}$ Palviainen \& Palviainen 2014, 5-7. https://docplayer.fi/479736-Mohko-kylamatkailuraportti.html

${ }^{28}$ Kokkonen 2005, 64-70.

${ }^{29}$ Möhkön ruukki 2019. https://mohkonruukki.fi/d/mohko-sodassa

${ }^{30}$ Utriainen 2014. https://yle.fi/uutiset/3-7404149
} 


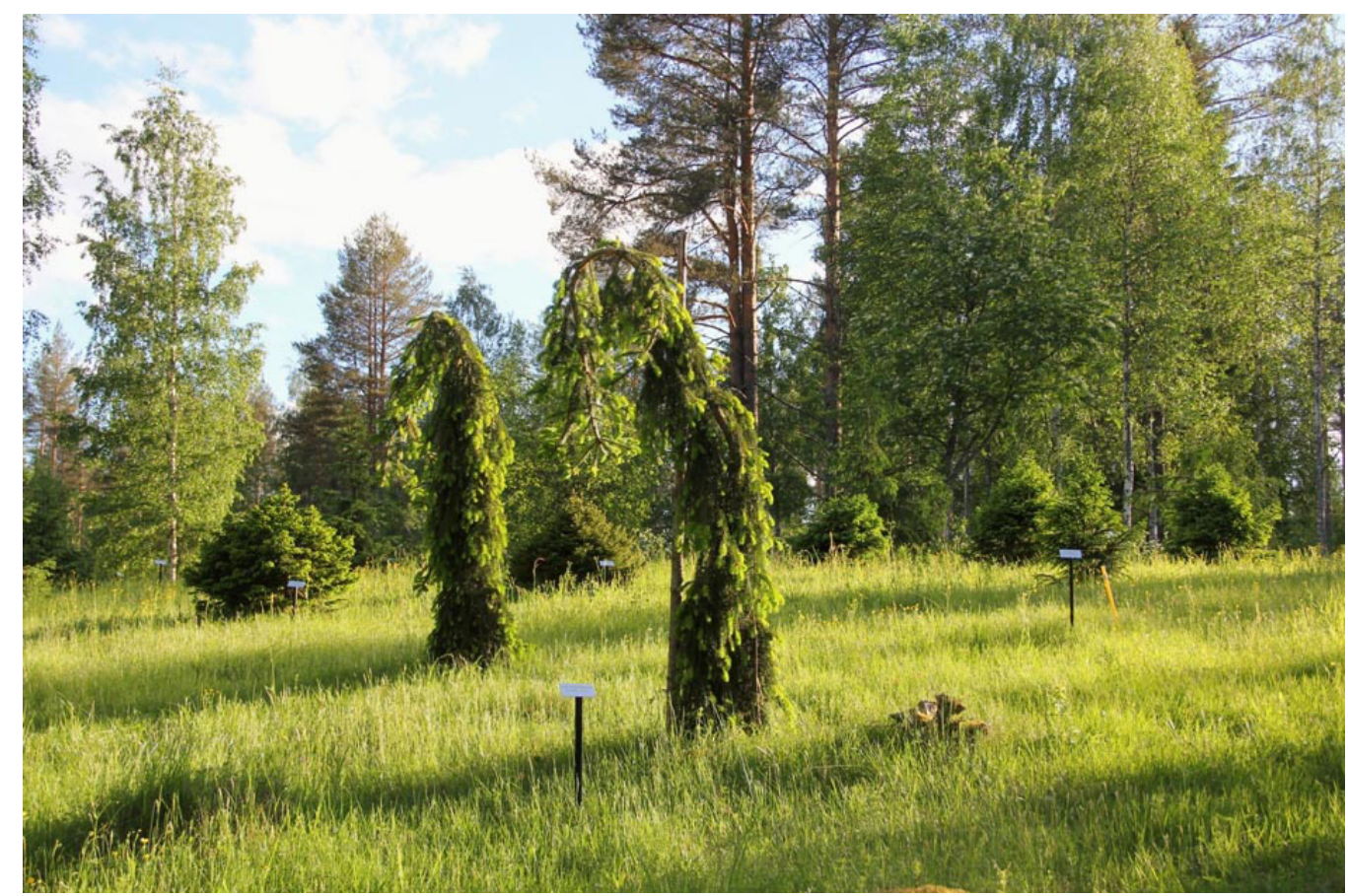

Kuva 2. Möhkön Arboretum. Kuvaaja Tommi Sorsa. Ilomantsin Museosäätiö.

luontomatkailun vyöhykkeen. Ruukin halki kulkee 100-kilometrinen Susitaipaleen reitti Petkeljärveltä, Möhkön, Ilajan ja Tapionahon kautta Koitajoen varteen ja siitä Hattuvaaran ja Naarvan kautta, Patvinsuolle. Reitin varrella on niin suojeltuja luontokohteita kuin tehometsätalouden aikaansaamia aukkoja, taimikoita ja metsäkoneilla vaikeakulkuisiksi muokattuja taipaleita.

Kulttuuritoiminnan ja matkailuelinkeinon näkökulmasta Möhköä ei voikaan luonnehtia syrjäiseksi kyläksi. Se on turistikohde ja Ilomantsin alueella tärkeä kulttuurikeskus. Möhkön kaltaisen pienen kylän vetovoimaksi eivät kuitenkaan riitä yksittäiset kohteet tai kylän aito kyläyhteisö, vaan historiallisen kohteen ympärille tarvitaan palveluita ja matkailijaa miellyttäviä ja kiinnostavia muita tekijöitä, jotta matkailija viihtyisi, tulisi uudelleen ja levittäisi sanaa käymisen arvoisesta kohteesta. Näitä palveluita ja kohteita Möhkön matkailuyrittäjät ja Möhkön matkailuyhdistys kehittävät.

\section{Luonnonvarojen käyttö, maiseman muutokset ja aineettomien luonnonvarojen merkitys nyky-Möhkössä}

Luonnonvarojen hyödyntäminen on muokannut Möhkön maisemaa ruukin syntyajoista lähtien. Aluksi kylän halki virtaava Koitajoki koki suurimmat muutokset, kun siihen rakennettiin voimalaitos ja kanava sekä tehtiin uittoperkauksia. Nämä syrjäyttivät tai ainakin asettivat toisarvoiseen asemaan muut vesistönkäyttömuodot, kuten kalastuksen intressit. Lisäksi joen veden laatua ovat kuormittaneet metsätalouden, maatalouden ja turvetuotannon ojitukset 
Kartta. Möhkön kylä, ruukkialue ja sen lähiympäristössä toteutetut ja suunnitellut hakkuualueet. Karttapiirros, Hilkka Heinonen 2019.

1950-luvulta lähtien. ${ }^{31}$ Sittemmin jokea on kunnostettu palauttamalla uittojen takia peratut kivet takaisin jokeen, poistamalla uittovarusteita, kunnostamalla kutusoraikkoja ja hillitsemällä kiintoaineiden pääsyä jokeen. Nykyinen joen virkistyskalastus ja matkailukäyttö kunnioittaa joen alkuperäistä olemusta. Joen taloudellisen merkityksen muutos fyysisestä voimanlähteestä ja kulku- ja kuljetusreitistä nykyiseksi virkistyskalastajien, melojien ja matkailijoiden arvostamaksi kohteeksi ja maisemaksi kuvastaa luonnonvarojen käytössä muutenkin havaittavaa suuntausta: raskaasta hyväksikäytöstä kohti aineettomampaa hyödyntämistä.

Myös metsiä on käytetty teolliseen toimintaan jo ruukin energiana. Tarvitsemansa puuhiilen saannin tur-

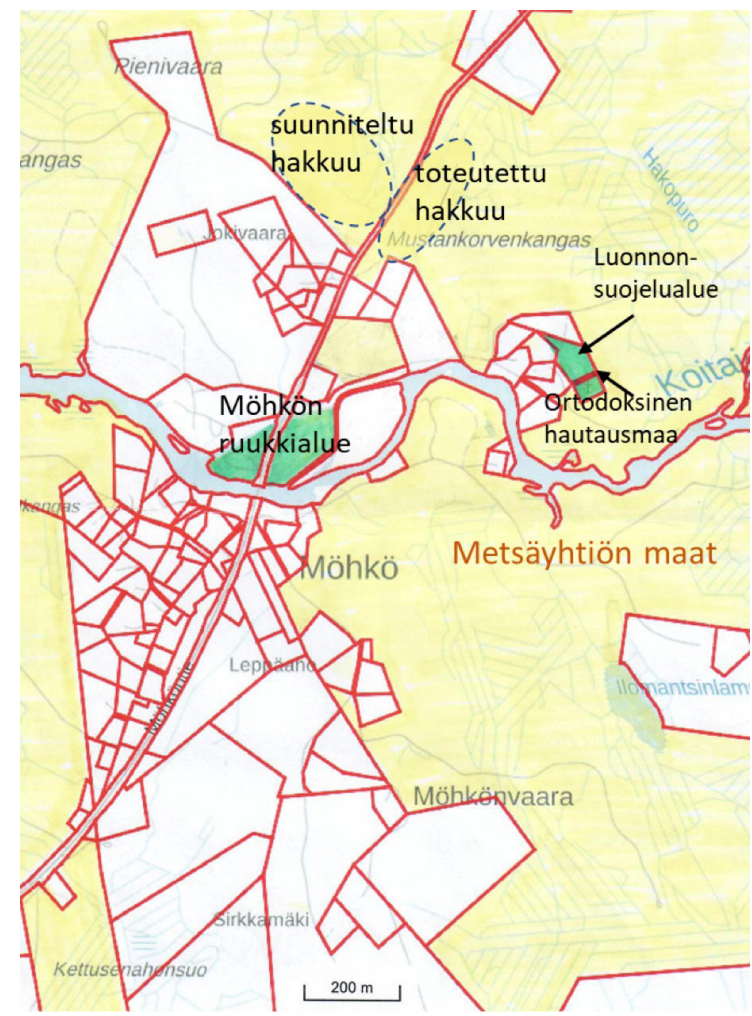
vaamiseksi oli ruukille hankittu 1800-luvun jälkipuoliskolla laajoja metsäalueita. Oma puu riitti noin puoleen tarpeesta, loppuosa ostettiin talonpojilta ja valtiolta. ${ }^{32}$ Metsien hakkuut avarsivat ja lehtipuuvaltaistivat metsämaisemia, joskaan ruukkien puuntarve ei ollut kovin merkittävä puupulaa aiheuttava tekijä. ${ }^{33}$ Ruukin metsät siirtyivät ruukin toiminnan loputtua vuonna 1908 W. Gutzeit \& Co:n omistukseen. Metsiä hyödynnettiin Möhkön sahalla aina vuoteen 1960 saakka. Sotien jälkeinen metsäpolitiikka ja metsänhoitosuositukset ovat jättäneet jälkensä Möhkönkin ympäristöön. Aikoinaan kylän kehityksen taannut ruukin laaja metsäomistus on kääntynyt metsäyhtiöiden valtakunnanlaajuisten metsien tehokäytöksi, jossa paikallisen näkökulman esiin saaminen on ollut satunnaista. Viimeisin omistajanvaihdos alueen metsissä tapahtui, kun UPM-kymmene myi metsät Tornator Oy:lle vuonna 2017. Nykyään Möhkön kylän kohtalo on vahvasti sidoksissa sitä ympäröivien metsien kohtaloon ja suurmetsänomistaja Tornator Oy:n metsäpolitiikkaan. Kylä on nykyään metsäyhtiön maiden "saartama", ja kyläläisille ja matkailuelinkeinolle tärkeäksi muodostuneen luonnonvaran, maiseman, kohtalo on pitkälti kyläläisistä riippumattoman toimijan vallassa. (ks. kartta).

Möhkön kylän elämä on perustunut luonnonvarojen raskaaseen teolliseen käyttöön. Matkailuelinkeino on muuttamassa tilannetta kohti luonnonvarojen aineettomampaa hyödyntämistä. Tämä noudattaa yleistä yhteiskunnassa ilmenevää kehityskulkua. Viime aikoina

\footnotetext{
${ }^{31}$ Albrecht 2018.

32 Björn 1999, 63; Kokkonen 2005.

${ }^{33}$ Harjunpää 2011, 53. http://epublications.uef.fi/pub/urn_nbn_fi_uef-20110035/urn_nbn_fi_uef-20110035. pdf
} 
metsäluonnonvara on saanut uusia merkityksiä. Vaikka puuntuotanto on valtakunnan tasolla edelleen metsien käyttöä hallitseva käyttömuoto, erilaiset metsäluonnonvaran aineettomien hyödykkeiden, kuten maiseman tai terveysvaikutusten, taloudellinen merkitys on kasvanut.

\section{Kylän ja valtakunnallisten yhtiöiden intressien yhteensovitushaasteet}

\section{Luonnonvarojen käytön paineet kylän ympäristössä ja lainsäädännön määrittelemät puitteet eri elinkeinoille}

Matkailusta on muodostunut tärkeä elinkeino syrjäisille seuduille, joilla maanviljely ei ole kyllin tuottavaa. Möhkön nykytoimijoille ruukki ja sen lähiluonto ovat kylän elinvoiman ehto. Alati tärkeämpinä korostuvat vesistön puhtaus, luonnon monimuotoisuus ja maisemat. Ruukin kulttuuriperintö kytkeytyy luontomatkailun intressien kautta ruukkiympäristöä ympäröivään lähiluontoon, jossa vallalla ovat luonnonvaroja hyödyntävät maankäyttömuodot ja niihin sisältyvät paineet. Lähellä sijaitsevien luonnonvarojen hyödyntäminen voi aiheuttaa ympäristövaikutuksia ja ristiriitaisia maankäyttöpaineita ruukin toiminnan kannalta. Tämä yhteenkietoutuminen vaatii ymmärrystä ja uudenlaisia toimintatapoja kaikilta alueilla toimivilta elinkeinotoimijoilta, maanomistajilta ja ympäristöpäätöksiä tekeviltä tahoilta. Olennaista on, miten ruukkikylän toimijoiden esittämiin alue- ja ympäristötavoitteisiin suhtaudutaan kunnan ja maakunnan maankäytön suunnitelmissa.

Möhkön ruukin toimijat haluavat vaikuttaa ruukin ympäristön metsänkäyttöön siten, että se tukee alueen sotahistoriallista luonnetta. Tämä vaatii eri toimijoiden välisiä neuvotteluja, sillä juridisia perusteita metsän käytön rajoittamiseen ei ole. Lähiympäristöä voidaan muuttaa ruukkitoimijoiden mielipiteitä ja perusteluja kysymättä.

Kysymys kohdistuu siihen, millä ehdoilla ja miten ruukkitoimijat voivat suojella ruukin lähiympäristöä? 'Tai miten he voivat vaikuttaa ruukin lähiympäristön säilymiseen sellaisena kuin se heidän kannaltaan on järkevää? Kysymys on tällöin siitä, miten ruukin lähiluonnon merkitys näyttäytyy eri toimijoille ja paljonko ympäristöpoliittista painoarvoa toisaalta suojelu ja toisaalta luonnonvarojen hyödyntäminen saavat. Tämä linkittyy kysymykseen siitä, millainen on luonnon tarjoamien aineellisten ja aineettomien palvelujen eli ekosysteemipalveluiden ympäristöoikeudellinen asema.

Luonnon ihmiselle tuottamista ilmaisista, aineellisista ja aineettomista hyödyistä ts. ekosysteemipalveluista on tullut tärkeä osa ympäristöhallintaa. Metsä-, kaivos- ja turvetuotannolla on kuitenkin aivan erilainen valta-asema lainsäädännössä kuin ekosysteemipalveluilla, joita ei juurikaan lakiteksteissä esiinny. Matkailuelinkeino hyödyntää Möhkössä paitsi kulttuurihistoriaa myös ekosysteemipalveluja. Ekosysteemipalvelut, kuten maisema, metsien terveys- ja virkistyskäyttö tai jokamiehenoikeudet eivät nauti lain suojaa. Kun asiasta ei ole lainsäädäntöä, sitä ei voida myöskään lain keinoin edistää tai suojella. Aineellisia luonnonvaroja kuluttavat hyödyntämistavat, kuten metsien puutavaran hankinta, kaivosmineraalien louhinta tai turpeennosto ovat lailla säädeltyjä, mutta myös laissa oikeutuksensa saavia luonnonvarojen käyttömuotoja. Sen sijaan aineettomat luonnonvarat (maisema, metsän pienilmasto, linnunlaulu tai metsän tuoksu tai muut elämyksellisten luontokokemusten lähteet) eivät nauti lain suojaa, vaikka toimivatkin elinkeinon perustana. ${ }^{34}$

\footnotetext{
${ }^{34}$ Katso lisää luonnonvarojen oikeudellisesta asemasta esim. Kuusiniemi ym:Ympäristöoikeus 2013, jakso IV Luonnonvarojen hyödyntäminen, Pärnänen 2012 ja Similä 2010.
} 
Möhkössä kylää ympäröivien metsien metsänhoito vaikuttaa suoraan matkailuelinkeinon toimintaedellytyksiin. Historiakohteiden hyödyntäminen kulttuuripolkureiteillä törmää puunkäyttöön metsätalouden materiaalina. Kuten kartasta ilmenee, Möhkön kylä on tiukasti metsäyhtiön metsien ympäröimä, joten metsänhoitotoimet vaikuttavat suoraan kylän maisemaan. Yhtiöllä ei kuitenkaan ole minkäänlaista lakiin perustuvaa velvollisuutta ottaa huomioon hakkuiden, maanmuokkausten ja muiden metsänhoitotoimien vaikutuksia maisemaan tai virkistyskäytön mahdollisuuksiin. Myöskään metsäkeskuksen viranomaisilla ei ole tällaista velvollisuutta eikä mahdollisuuttakaan. ${ }^{35}$

Metsän käyttö on vahvasti maanomistajan oikeus ja hänen määräysvallassaan. Naapuruston kannalta tilanne on samankaltainen kuin kaivoslain mukaan toimittaessa: naapureilla ei juurikaan ole sananvaltaa siihen, miten naapurin metsiä hoidetaan ja käytetään. Sen sijaan muiden luonnonvarojen hyödyntäminen (maa-ainesten otto, turpeen otto, vesialueiden hyödyntäminen, rakentaminen) on pääosin luvanvaraista ja siten myös naapureilla on mahdollisuus ottaa kantaa lupaprosessin eri vaiheissa. Metsälain mukaan toimittaessa naapurimaanomistajat voivat tulla "yllätetyiksi" avohakkuilla ilman ennakkovaroitusta. Metsänkäyttöilmoitus on se menettely, jonka kautta metsien hakkuita kontrolloidaan viranomaisessa. Näitä ilmoituksia tehdään noin 100000 vuosittain, mikä tarkoittaa, ettei kyseisten ilmoitusten valvonta voi olla aukotonta, eikä viranomaisella ole mahdollista käyttää sillä mahdollisesti olevaa harkintavaltaa muuta kuin kaikkein kriittisimmiksi tunnistetuissa kohteissa.

Aineellisia luonnonvaroja käyttävien toimintojen perusteluna käytetään maanomistusta (kaivostoimintaa lukuun ottamatta). Kuitenkaan omistusoikeus ei takaa täydellistä käyttövapautta, vaan käytössä on kunnioitettava myös muiden omistajien oikeuksia oman omaisuutensa käyttöön. Jo satavuotiaan naapuruussuhdelain periaate "Kiinteistön käyttöä rajoittaa se, ettei sen käytöstä saa aiheutua (kohtuuttomia) rajoitteita toisen kiinteistön käytölle" kuvastaa tätä ikiaikaista periaatetta. ${ }^{36}$ Jos periaate tuodaan tämän päivän todellisuuteen ekosysteemipalveluiden kautta, voidaan esimerkiksi kysymykset metsien hakkuista, ojituksista ja maanmuokkauksista asettaa samaan keskusteluun kuin matkailuelinkeinon kehittämismahdollisuudet.

Turvetuotanto ja maa-ainesten otto ovat pääsääntöisesti luvanvaraisia ja niiden ottoa säädellään ympäristönsuojelu- ja maa-aineslailla. ${ }^{37}$ Maa-aineslaissa on alusta lähtien (1980-luvulta) ollut velvollisuus huomioida maisemalliset tekijät sekä luvan myöntämisvaiheessa että ottotoiminnan päätyttyä maisemointivaiheessa. Maanomistus antaa lähtökohtaisen oikeuden maa-ainesten hyödyntämiseen, mutta lupamenettely antaa yhteiskunnalle mahdollisuuden ottaa huomioon myös muut arvot, jotka mahdollisesti ovat vastakkaisia maa-ainesten hyödyntämiselle. Turvetuotantoluvissa keskitytään turpeennoston vesistövaikutuksiin sekä terveydellisiin vaikutuksiin, kuten melu- ja pölyhaittoihin. Maisemallisilla tekijöillä ei ole vaikutusta luvan myöntämiseen. Lupamenettelyssä annetaan mahdollisuus myös sivullisille vaikuttaa luvan sisältöön. Koska lupamenettely ei ole joko-tai -luonteista, voidaan lupamääräyksissä ottaa huomioon monenlaisia tekijöitä, kuten ottoalueen rajaus, syvyys ja kesto. Myös ympäröivän alueen intressit voidaan ainakin osittain sovittaa yhteen ottotoiminannan kanssa. Metsälain mukainen metsien hyödyntäminen poikkeaa jyrkästi näistä maankäyttömuodoista, koska metsien käyttö ei ole luvan- vaan ilmoituksenvaraista.

\footnotetext{
35 Katso metsälaki (1093/1996) ja esim. Kuusiniemi ym.: Ympäristöoikeus 2013, jakso IV Luonnonvarojen hyödyntäminen alajakso 2. Metsienkäyttö.

${ }^{36}$ Katso naapuruussuhdelaki (26/1920) 17-18 §.

${ }^{37}$ Katso ympäristönsuojelulaki 527/2014 luku 4 ja maa-aineslaki 555/1981.
} 
Perustuslaki takaa jokaiselle oikeuden vaikuttaa omaa elinympäristöään koskevaan päätöksentekoon. Tämän katsotaan toteutuvan, kun kansalaisella on esimerkiksi valitusoikeus ympäristölupapäätöksistä tai muistutusmahdollisuus kaavoituksesta. Möhkön tapauksessa tuo perusoikeus jää jossain määrin vajaaksi, koska metsäympäristö on oleellinen osa kylän ympäristöä, mutta metsälaki ei anna kyläläisille minkäänlaista osallistumismahdollisuutta metsiä koskevaan päätöksentekoon. Kylää ei myöskään tunnisteta virallisessa päätöksenteossa oikeudelliseksi toimijaksi. Toimijoita ovat joko yksittäiset kansalaiset, kyläläisten muodostamat rekisteröidyt yhdistykset (kyläyhdistys, asukasyhdistys, maamiesseura, metsästysseura tms.) tai seuraavana kokonaisuutena kunta. Tämä on haasteellista asukasdemokratian kannalta, mutta myös kylän mahdollisen "yhteisen tahdon" vaikuttavuuden kannalta. Kylä tarvitsee vahvoja, kylän nimissä toimivia henkilöitä, jolloin vaikuttavuus riippuu pitkälti henkilöiden ominaisuuksista, neuvottelutaidoista, halusta ja mahdollisuuksista käyttää omaa aikaansa yhteiseksi hyväksi. Jos kylällä ei ole tällaisia henkilöitä, kylän ääni hukkuu lausuntopinoihin ja virallisiin näkemyksiin.

Matkailuyhdistykselle neuvottelutilan aikaansaaminen on erittäin tärkeää. Puukauppa toimii olemassa olevien toimintakäytäntöjen pohjalta. Metsää muokataan siten, että puu kasvaa metsäteollisuuden vaatimusten mukaisesti. Luontomatkailu, joka limittyy metsätalous- ja turvetuotantoalueisiin, ei tuo sellaisia aluetaloudellisia tuloja, ainakaan vielä, kuin metsätalous.

Laajojenkin metsähakkuiden tai muiden metsänhoitotoimien ennakollinen tiedottaminen "asianosaisille" on täysin hakkuiden suorittajan vapaaehtoisen tiedottamisen varassa. Metsänkäyttöilmoituksia ei tarvitse saattaa naapurien tiedoksi. Tämä on jyrkässä ristiriidassa esimerkiksi maankäyttö- ja rakennuslain mukaisen ilmoitusvelvollisuuden kanssa, jonka mukaan varsin vähäisistäkin rakennushankkeista on tiedotettava naapureille. Möhkössä tähän epäkohtaan törmättiin kesällä 2018, kun metsäyhtiö avohakkasi kylän pohjoislaidalla olevan metsäkuvionsa ja tuhosi samalla matkailuyritysten aktiivisesti käyttämän sotahistoriallisen polun nähtävyyksineen. Freshabit Koitajoki ja Soviko-projektin yhteydessä on rakennettu kyläläisten ja metsäyhtiön välille keskusteluyhteyttä. Konkreettisia neuvotteluja käytiin keväällä 2019. Yhteisessä neuvonpidossa pohdittiin mahdollisuuksia, jotta vastaavien tapahtumien toistuminen estettäisiin. Lisäksi neuvotteluissa tuotiin esiin kyläläisille erityisen tärkeitä kohteita, jotta yhtiö voisi ottaa ne huomioon hakkuusuunnitelmia tehdessään. Neuvottelut käytiin hyvässä hengessä ja tuloksena yhtiö ja kyläläiset sopivat vastaavan yhteydenpidon jatkuvan vuosittain.

Neuvonpito ja sen tulokset vahvistivat tutkijoiden käsitystä siitä, että ns. yhteishallintaa on mahdollista kehittää ja että osapuolten yhteen saattaminen neuvotteluihin voi jo itsessään tuoda ratkaisuja ongelmatilanteisiin.

Ruukkikylän tulevaisuutta rakennetaan matkailuelinkeinon varassa. Kylän kannalta tärkeä kysymys on, miten alueen tekninen historia, nykyinen metsätalouden valta-asema ja matkailun kehitys saadaan toimimaan yhdessä siten, että ne tukevat toisiaan sen sijaan, että niiden risteävät edut estäisivät toistensa kehittymistä. Kyläläisten pitkäjänteinen työ matkailuelinkeinon edistämiseksi voi valua hukkaan yhdellä metsäyhtiön hakkuupäätöksellä. Kyse onkin metsänkäsittelytoimien mittakaavasta ja pienipiirteisyyden huomioon ottamisesta. Suurelle metsäyhtiölle metsät ovat motteja ja hehtaareja, toiset hehtaarit tuottoisampia kuin toiset. Yhtiön tulostavoitteisiin eivät välttämättä mahdu neuvottelut "jokaisen kylän pienipiirteisten toiveiden" kuuntelusta ja toteuttamisesta. 
Kuva 3. Möhkön ruukin lähiympäristössä toteutettu hakkuualue. Kuva Hilkka Heinonen 2018.

Ruukkikylän tulevaisuuden suunnitelmia varjostaa se, että tekniseen kehitykseen perustuvilla luonnonvaroja hyödyntävillä elinkeinoilla on etulyöntiasema luonnonvarojen hyödyntämisessä. Onko se välttämätöntä vai pitäisikö myös muiden alojen kehitykselle jättää tasavertaiset mahdollisuudet? Onko luonnon-

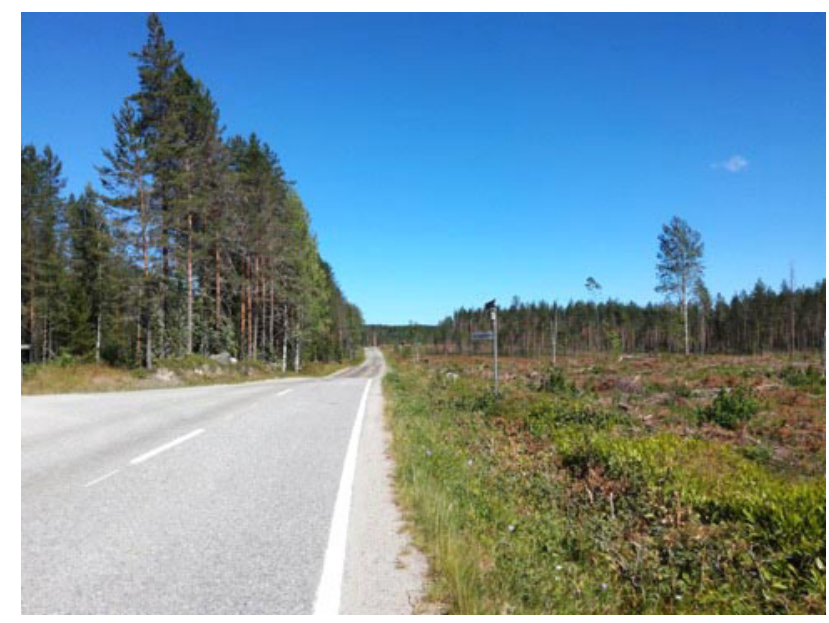
varoja vähentävä käyttö hyväksyttävämpää elinkeinotoimintaa kuin niiden kuluttamaton käyttö? Tätä olisi syytä pohtia laajemminkin ympäristölainsäädäntöä kehitettäessä.

\section{Tulevaisuuden kuvia}

Möhkön ruukkiympäristön ylläpitämisessä on näkyvillä kehitys, jossa teollisen perinnön suojelun perusteet kohtaavat luontopalvelujen säilyttämisen tavoitteet. Se, miten ekosysteemipalvelujen asema lainsäädännössä ymmärretään ja millaiseksi se lopulta muotoutuu, tulee heijastumaan myös kulttuuri- ja luonnonympäristön välisen suhteeseen.

Luontomatkailun tavoitteet kytkeytyvät muihin taloudellis-ekologisia muutoksia vaativiin ajattelutapoihin, joista vaikuttavin on ilmastonmuutoksen hillintä ja siihen sopeutuminen. Talousmetsiä koskevissa hoitotavoitteissa on kuluvalla vuosikymmenellä nostettu tavoitteiksi alue-ekologisen suunnittelun soveltaminen ja monimuotoisen lajiston turvaami$n^{38}{ }^{38}$. Myös vesistökuormituksen vähentämisen vaatimukset ovat metsäojituksia koskevien jatkuvien tutkimusten ja Euroopan unionin vesipuitedirektiivin voimaantulon myötä vahvistuneet $^{39}$. Nämä tekijät ovat ekosysteemipalvelujen ja luontomatkailutoimijoiden kannalta tärkeitä suuntaviivoja. Mutta niiden esiin nostaminen vaatii paikallistason toimijoiden aktivoitumista ja uusia vuorovaikutteisia avauksia, joissa myös epävirallinen kulttuuriympäristö tulee huomioida merkittävänä argumenttina.

Metsätalouden ja -hakkuiden lisäksi Möhkön matkailulla on eräitä muitakin luonnonvarojen käyttöön liittyviä uhkakuvia. Ilomantsin turvesuot ovat olleet merkittävä tulonlähde Vapo Oy:lle vuosikymmenien ajan. Biotalous ja Ilomantsiin rakenteilla oleva biohiilitehdas ovat tuomassa turpeelle uusia käyttömuotoja ja jalostusasteen nostamista poltto-, kuivike- ja kasvuturpeeseen verrattuna. Möhkön läheisyydessä oleva Mäkräsuo on varattu turvetuotantoalueeksi maakuntakaavassa ja Vapo Oy pitää tiukasti kiinni haltuunsa hankkimistaan turvevaroista. Teknologian kehitys on tuonut tullessaan siis jälleen uuden haasteen kylän tu-

\footnotetext{
${ }^{38}$ Kuuluvainen et.al. 2004. https://helda.helsinki.fi/handle/10138/16508

${ }^{39}$ Palviainen \& Finer 2013, 6.
} 
levaisuudelle: hyödynnetäänkö kylän ympäristön soita turpeennostoon siten, että jokiveden laatu ja hoidettu kalasto on uhattuna, puhdas ilma ja suomaisemat mennyttä?

Möhkön kylä syntyi järvimalmin jalostajaksi. Järviraudan merkitys hiipui tehokkaampien rautamalmin rikastusmenetelmien kehityttyä. Kaivosteollisuus tai malminjalostus eivät jatkuneet Möhkössä, vaikka kaivosteollisuudella on edelleen vankka jalansija Ilomantsissa. Karjalan kultalinjana tunnettu malmivyöhyke ei ainakaan nykytietojen mukaan yllä kylän välittömään läheisyyteen. Tosin 23.3.2019 hyväksytty varausilmoitus tulee lähemmäksi Möhkön kylää $(7,7 \mathrm{~km})$ kuin aiemmat malminetsintäalueet. On siis mahdollista, että tulevaisuudessa kylän läheisyydessä koetaan uusi kaivosteollisuuden tuleminen, nyt kuitenkin kultamalmin takia.

Toistaiseksi luonto- ja kulttuurimatkailu on pienimuotoista kansallisesti merkittävien luonnonvarayhtiöiden rinnalla, mutta luontopalveluja koskevien ajattelutapojen muuttuminen tekee työtä sen eduksi. Yhtä tärkeää on kulttuuriväen ja asukkaiden verkostoituminen. Möhkössä kulttuuri- ja luontomatkailun yhdistys on kasvanut kyläyhteisöä vaikuttavammaksi toimijaksi. Sitä voi verrata kehityskulkuun Lieksan Ruunaan alueella 2000-luvun alkupuolella, jossa luontomatkailun elinkeinoyhteisö kehittyi vahvaksi toimijaksi kyläyhteisön rinnalle samalla kun metsätalous menetti merkitystään alueen käyttömuotoja koskevassa päätöksenteossa ${ }^{40}$. Möhkön matkailuyhdistys, johon kuuluvat myös Möhkön ruukin museotoiminnasta vastaava Ilomantsin museosäätiö, alueen matkailuyritykset ja Möhkön kyläyhdistys, kehittää luonto- ja kulttuurimatkailua sekä kylän että laajemman alueen elinvoiman edellytyksiä. Tämä kolminaisuus on synnyttänyt paikallisen osaamisen, joka vahvistaa ruukkikylän elinvoimaa. Se tulisi huomioida myös ruukkikylän lähiympäristöä ja toiminnallisesti laajempia alueita koskevissa maankäytön suunnitelmissa.

40 Eisto 2009,158-159.

\section{Lähteet}

Albrecth, Eerika 2018. Ilomantsin luonnonvarojen käytön historiaa Koitajoen ympäristön tilan muutosten kuvaajana. PohjoisKarjalan elinkeino-, liikenne- ja ympäristökeskus. Raportteja 49/2019. Viimeksi muokattu 2019.

Arpiainen, Eija 2016. Eheytyvän elinympäristön jäljillä Kangasalan Suoramalla. Tampereen yliopisto Johtamiskorkeakoulu Ympäristöpolitiikan ja aluetieteen opintosuunta Pro gradu -tutkielma toukokuu 2016.

Björn, Ismo 1991. Suur-Ilomantsin historia. Enon, Ilomantsin ja Tuupovaaran historia vuoteen 1860. Enon, llomantsin ja Tuupovaaran paikallishistoriatoimikunta. Sisälähetysseuran kirjapaino Raamattutalo. Pieksämäki.

Björn, Ismo 1991. Kaikki irti metsästä. Metsän käyttö ja muutos taigan reunalla itäisimmässä Suomessa erätaloudesta vuoteen 2000. Suomen Historiallinen Seura. Helsinki 1999.

Björn, Ismo 2006. Ilomantsin historia. Ilomantsin ja Tuupovaaran historiatoimikunta. Keuruu.

Eisto, Ilkka 2009. Kylläpä kestää. Paikallisesti kestävän kehityksen ja ympäristölähtöisen kehittämistoiminnan suhde harvaanasutulla maaseudulla. Joensuun yliopiston yhteiskuntatieteellisiä julkaisuja nro 101. Joensuun yliopistopaino. 
Fairglouch, Graham 2012. Others: a prologue. Teoksessa, Elisa Ciaccardi (toim.), Heritage and social media. Understanding heritage in a participatory culture. Routledge. London.

Grahn, Heidi 2013. Kuparin hohtoinen ruukinmaisema. Kuparin kyydissä Orijärven kaivokselta Kärkelän ja Kosken ruukeille. Viimeksi muokattu 2013. https://www.salo.fi/attachements/2015-10-06T08-08-4992.pdf

Grahn, Maarit 2014. Perheyhtiö ja paikallisuus. A. Ahlström Osakeyhtiön historian perintö Noormarkussa. Annales Universitatis Turkuensis C 374 Turun yliopisto. Viimeksi muokattu 2014. https://www.utupub.fi/ handle/10024/94239

GTK 2002. Suomen tietoaineisto. Ruukit. Viimeksi muokattu 2002. http://weppi.gtk.fi/aineistot/kaivosteollisuus/RUUKIT.htm

Haanpää, Riina, Puolamäki, Laura, Raike, Eeva 2018. Tapaus Eurajoki: ihmisen ja ympäristön vuorovaikutussuhde tutkimuskohteena. Teoksessa Pilvi Hämeenaho, Tiina Suopajärvi ja Johanna Ylipulli (toim.), Soveltava kulttuuritutkimus. Tietolipas 259/SKS. Juvenes Print - Suomen yliopistopaino. Tampere.

Harjunpää, Kaisa 2011. Möhkön rautaruukin vaikutukset llomantsin metsiin 1849-1907. Yleisen historian pro gradu -tutkielma. Itä-Suomen yliopisto. Historian oppiaineryhmä. Viimeksi muokattu 2011. http://epublications.uef.fi/pub/urn_nbn_fi_uef-20110035/urn_nbn_fi_uef-20110035.pdf

Heikkinen, T. 2009. Paikallinen tilaus eheyttämisen lähtökohtana. Teoksessa Sairinen, R. (toim.) Yhdyskuntarakenteen eheyttäminen ja elinympäristön laatu. Yhdyskuntasuunnittelun tutkimus-ja koulutuskeskuksen julkaisuja B 96, 187-230. Espoo: Teknillinen korkeakoulu

Ikonen, Jorma 2015. Kyläjoen mutkassa Möhkö. Laser Media Oy. Joensuu

Immonen, V., Mäki, M., \& Taavitsainen, J.-P. 2018. Tutkimuksen ja kulttuuriperinnön jännitteitä: Teollisuusarkeologian historia Suomessa. Tekniikan Waiheita, 36(3), 22-38. Viimeksi muokattu 2018. https://journal.fi/ tekniikanwaiheita/article/view/82367

Kahila, Petri 2001. Perinnettä vai bisnestä. Kaksi maaseudun kulttuurimatkailun kohdetta: Hämes-Havunen ja Bunratty folk Park. Teoksessa Sulvevi Riukulehto (toim.) Kulttuurin paikalliset ulottuvuudet. Gummerrus Kirjapaino Oy. Saarijärvi.

Kallio, Titta 2005. Teollisuusarkeologiaa Suomessa. Tutkimustapoja ja ongelmia. Tekniikan Waiheita 3/2005. s. $40-50$.

Kokkonen, Jukka 2005. Villiä itää, kesytöntä länttä - Ylä-Koitajoen alueen ja llomantsin historiaa. Metsähallituksen luonnonsuojelujulkaisuja. Sarja A 152. Metsähallitus.

Korvenmaa, Pekka 1989. Kauttua: tuotanto ja ympäristö 1689-1989. Ahlström, 1989.

Kujala, Irene 2006. Kulttuuriympäristökokemukset suunnittelutietona: Ruukin kulttuuriympäristöön liittyvä kokemusperäinen tieto ja sen hyödyntäminen suunnittelussa. Tampereen yliopisto/ Yhdyskuntatieteiden laitos Aluetieteen pro gradu -tutkielma. Viimeksi muokattu 2006. https://trepo.tuni.fi/bitstream/ handle/10024/93554/gradu01149.pdf?sequence =1\&isAllowed $=y$

Kuuluvainen, Timo; Saaristo, Lauri; Keto-Tokoi, Petri; Kostamo, Jouko; Kuuluvainen, Jari; Kuusinen, Mikko; Ollikainen, Markku; Salpakivi-Salomaa, Päivi 2004. Metsän kätköissä Suomen metsäluonnon monimuotoisuus. FIBRE/Edita Publishing Oy. Viimeksi muokattu 2004. https://helda.helsinki.fi/handle/10138/16508

Kuusiniemi, Kari, Ekroos, Ari, Kumpula, Anne, Vihervuori, Pekka 2013. Ympäristöoikeus. Oikeuden perusteokset. Sanoma Pro. Helsinki.

Matthes, Erich Hatala 2018. "The Ethics of Cultural Heritage “, The Stanford Encyclopedia of Philosophy (Fall 2018 Edition), Edward N. Zalta (ed.). Viimeksi muokattu 2018. https://plato.stanford.edu/archives/fall2018/ entries/ethics-cultural-heritage/

Museovirasto restauroi 2013. Möhkön ruukki, llomantsi. Viimeksi muokattu 2013. http://museovirastorestauroi.nba.fi/teollisuuskohteet/mohkon-ruukki

Museovirasto 2009. Valtakunnallisesti merkittävät rakennetut kulttuuriympäristöt RKY. Viimeksi muokattu 2009. http://www.rky.fi/read/asp/r_default.aspx

Möhkön ruukki 2019. Möhkö sodassa. https://mohkonruukki.fi/d/mohko-sodassa

Palviainen, Marjo, Finér, Leena 2013. Kunnostusojituksen vaikutus vesistöjen humuskuormitukseen. Taso. Kopijyvä. Jyväskylä.

Palviainen, Soila, Palviainen, Simo 2014. Möhkö. Kylämatkailuraportti. Matkailu- ja ympäristövalmennus Entra Ky. Viimeksi muokattu 2014. https://docplayer.fi/479736-Mohko-kylamatkailuraportti.html

Peltonen, Lasse, Villanen, Sampo 2004. Maankäytön konfliktit ja niiden ratkaisumahdollisuudet. Suomen ympäristö 723. Ympäristöministeriö. Alueidenkäytön osasto. Helsinki.

Pärnänen, Sinikka 2012. Luontoarvojen huomioon ottaminen ympäristönsuojelulain ja eräiden muiden lakien mukaisessa lupamenettelyssä. Selvitys, ympäristöministeriö. 
Rojek, Chris 1997. Ways of Escape. Modern Transformations in Leisure and Travel. The Mcmillian Press. London.

Siivonen, Katriina 2012. Kulttuuriperintö itseisarvona ilman välinearvoa. Elore (ISSN 1456-3010), vol. 19 1/2012. Suomen Kansantietouden Tutkijain Seura ry. Viimeksi muokattu 2012. http://www.elore.fi/arkisto/1_12/siivonen.pdf

Similä, Jukka 2010. Ekosysteemipalvelut ja sääntely: Teoksessa Hyödyllinen luonto Ekosysteemipalvelut hyvinvointimme perustana. Vastapaino, Tampere.

Utriainen, Jyrki 2014. "Vetäytymiskäskyä ei tule: tähän kuollaan tai venäläiset pysäytetään" - jatkosodan ratkaisevia taisteluja sopii muistella llomantsin Möhkössä. Viimeksi muokattu 2014. https://yle.fi/uutiset/3-7404149 